\title{
Features
}

\section{The 50th Anniversary of Brown v. Board of Education: Continued Impacts on Minority Life Science Education}

\section{Irelene Ricks}

\author{
Director of Minorities Affairs, The American Society for Cell Biology
}

\section{A BRIEF HISTORY OF AFFIRMATIVE ACTION IN THE UNITED STATES}

The landmark case of Brown v. Board of Education of Topeka, $K S$, was actually a compilation of civil rights cases that argued for the elimination of the "separate but equal" principle that had shaped the relationship between African Americans and whites since the Plessy v. Ferguson U.S. Supreme Court decision of 1896. Once established as de jure law, it would take another judicial rendering by the U.S. Supreme Court to overturn Plessy. In arguing Brown v. Board of Education, the National Association for the Advancement of Colored People (NAACP) recognized the Supreme Court's preference for historical precedent and debated educational reform within the context of Plessy's violation of the 14th Amendment (passed in 1868), which protected former slaves and their descendants from unconstitutional acts. In winning Brown, the NAACP was successful in reshaping policies regarding public education in the United States.

The May 17, 1954, decision in the Brown case did more than allow minority and nonminority children the opportunity to be educated together without regard to racial distinction; it also signaled a sea change in which AfricanAmerican students would henceforth have legally entitled access to the same public academic institutions as their white counterparts. Racial integration of postsecondary educational institutions had been decided by the Court prior to Brown, but fair and equal access to quality education in all sectors (public, private, and independent) gained more currency with the Brown decision and moved the education debate to center stage in the public discourse on race.

Minimizing the consequences of slavery and racial separation was the original intention of affirmative action and has been used (or misused) as an instrument of public policy by every U.S. president since John Kennedy. In a 1965 commencement address at Howard University, President Lyndon Johnson articulated the general philosophy of affirmative action: "You do not take a person, who for years, has been hobbled by chains and liberate him, bring him up to the starting line of a race and then say 'you are free to compete with all the others' and still believe that you are being completely fair."

\section{DOI: $10.1187 /$ cbe.04-05-0044}

* E-mail address: iricks@ascb.org.
Since 1965, legal barriers prohibiting minorities from receiving equal access to education have been dismantled. Attempts to challenge affirmative action in higher education (e.g., Bakke, 1978; Proposition 209, 1996; Hopwood, 1997) have been unsuccessful because most American institutions of higher education remain committed to the philosophy of affirmative action. It is disturbing, however, that 50 years after Brown, most minority students (from elementary through postdoctoral training), including minorities in the biological and biomedical sciences, continue to receive dramatically different educational experiences from their nonminority peers. For example, a 1990 RAND study revealed that "urban schools with a high proportion of economically disadvantaged or minority children typically offer less access to math and science education" (Clarke, n.d.). In grades 9 though 12, 29 percent of classes with a low proportion of minority children are labeled "low-ability," but 42 percent of the classes comprising at least 40 percent minority children are so labeled (National Science Foundation, 1996). Moreover, these distinctions can be attributed to a number of confounding factors, such as "poorer preparation to learn and inferior public schools" (coupled with low self-esteem) that reinforces negative self-imaging in which "minority students often labor under the suspicion that they are intellectually inferior-or, at least, they think that others regard them so-and the burden of trying to overcome that stereotype leads many of them to avoid academic competition by persuading themselves that grades are not really important" (Bok, 2003, p. B20).

\section{THE 2003 MICHIGAN DECISION: POLICIES FOR MINORITY LIFE SCIENTISTS}

When Martin Luther King Jr. stood on the steps of the Lincoln Memorial in 1963 to "dream" of a better future for the nation's children, he wondered how to create a democracy that would promote equality and utilize the talents of all people regardless of race. Forty years later, the U.S. Supreme Court issued another landmark decision on affirmative action (Grutter v. Bollinger [2003] and Gratz v. Bollinger [2003]; commonly referred to in the singular as the "Michigan decision"), upholding the use of race in higher education admissions decisions. In keeping with the philosophy of affirmative action, the Court concluded that "effective participation by members of all racial and ethnic groups in the civic life of our nation is essential if the dream 
of one Nation, indivisible, is to be realized." The majority of the Court agreed that a diverse student body "better prepares students for an increasingly diverse workforce and society, and better prepares them as professionals" (Supreme Court majority opinion, Grutter v. Bollinger, 2003).

Despite the Brown and Michigan decisions, educational and employment gaps persist-and in some cases are widening. For example, with respect to African Americans who received Ph.D. degrees in the life sciences in 2000-2001, there were approximately 190 doctoral graduates compared with 4,416 whites; 213 Hispanics, and 21 Native Americans. Professorships were down by 11.3 percent for AfricanAmerican women and 7.2 percent for African-American men at the highest levels of the professoriate. In other words, African Americans are underrepresented at both the bottom and the top levels of the life sciences; Hispanics are faring a bit better than African Americans, but Native Americans lag significantly further behind (American Council on Education, 2003).

The language in the Michigan decision was unambiguous, but responses from many within institutions of higher education have helped to stall or even reverse progressive efforts to recruit and retain underrepresented groups in the scientific fields. A year later, the president of Rensselaer Polytechnic Institute, Shirley Ann Jackson, told the Annual Meeting of the American Association for the Advancement of Science how the nation can use minority talent to remain competitive scientifically in the face of a changing global economy. Jackson highlighted the asymmetry between a U.S. population composed of 35 percent minority groups and the traditional science, mathematics, engineering, and technology workforce that is nearly 82 percent white and more than 75 percent male. Given U.S. demographics, Jackson predicted that the workforce will be transformed into "the new majority - the underrepresented majority . . . that must fill the void left by retiring scientists, engineers, and technologists" (Jackson, 2004, p. 4). A commentary on the Michigan decision published in the Journal of the American Medical Association addresses the potential impact on minority physicians: "Until such time that students from all racial and ethnic backgrounds emerge from the educational pipeline with an equivalent range of academic credentials, there is simply no way for medical schools to fully meet their societal obligation without using race and ethnicity as explicit factors in admissions decisions" (Cohen, 2003, p. 1143).

In March 2004, the nation's largest publicly funded biomedical institution, the National Institutes of Health (NIH), sponsored a symposium to honor Brown, with more than 200 minority and nonminority NIH staff in attendance. The speakers represented scholars from education, political science, and medicine who addressed the continued paucity of minority students, researchers, and administrators at the nation's most prestigious institutions. There was concern and disappointment that the numbers of minorities have not grown with respect to medical school acceptance or completion of terminal research degrees, but few specific proposals were offered as remedies.

Young minority postdoctoral researchers, such as Dr. Chad Womack, regard Brown as a national decision to take the work and professional efforts of minority students and researchers as seriously as their nonminority peers. Conducting research on HIV/AIDS as a senior research fellow at the NIH Vaccine Research Center and acting as current president of the NIH Black Scientists' Association (NIH/ BSA), Womack is aware of how far the nation has come in half a century - and of how much work remains unfinished. Speaking as NIH/BSA president, Womack noted, "Fifty years after Brown, African Americans make up less than two percent of NIH RO1-funded principal investigators in the country, and minorities still comprise less than 2 percent of all tenured, tenure-track and/or research fellows within the $\mathrm{NIH}$ Intramural research program. While I acknowledge the momentous decision rendered some 50 years ago, it is clear that we have a long way to go." What do the numbers of underrepresented minorities mean, and how can we make a difference in reaching the goals of affirmative action?

\section{AFFIRMATIVE POLICIES FOR MINORITY EDU- CATION AND PROFESSIONAL DEVELOPMENT}

Started in 1985, The American Society for Cell Biology (ASCB) Minorities Affairs Committee (MAC) is currently chaired by Dr. Donella Wilson, with Dr. J.K. Haynes serving as vice chair. There are 14 members, including one AfricanAmerican postdoctoral fellow. MAC includes eight African Americans, two Hispanic/Latinos, one Native American, and four whites (Table 1). Wilson joined the committee in 1992 and is now director of research and promotion for the American Cancer Society in Atlanta. Over the past 19 years, MAC programs have flourished, including travel awards to the ASCB Annual Meeting and the Histochemical Society, an annual poster competition, summer courses at the Marine Biological Laboratory and Friday Harbor, a visiting professors program, and the Linkage Fellows program. Since 1985, MAC has involved nearly 2,000 minority students and scientists in its programs. Within the community of disciplinary societies, MAC is one of the acknowledged leaders in the professional development of minority scientists.

As chair of the Department of Biology at Howard University, one of the nation's top producers of science majors (National Science Foundation, 1999), Dr. William Eckberg appreciates the impact of Brown and Michigan. In commenting on the consequences of Michigan, Eckberg reflects on the fact that

\begin{abstract}
the Michigan decision said that universities can still use race/ethnicity as a factor in admission decisions, so it didn't really change anything. It is especially important that race continues to be a factor in admissions, given that the SAT and GRE [Scholastic Assessment Test and Graduate Record Examination] are poor predictors of minority students' academic success. Though it's too soon to know, I wouldn't expect the decision to have much impact on minority enrollments in the sciences. If the [Michigan] decision had gone the other way, it no doubt would have had a negative impact, especially at the undergraduate and professional levels, and education and American society would have been set back 50 years.
\end{abstract}

\section{HOW THE ASCB CAN IMPROVE THE MINORITY SCIENCE PIPELINE}

A recent U.S. News and World Report article on Brown suggested changing strategy for public education away from integration to accomplish racial balance to a strategy that focuses on integration as a tool related more specifically to 
Table 1. Composition of the American Society for Cell Biology Minority Affairs Committee (2004)

Donella Wilson, Ph.D. (chair)

J.K. Haynes, Ph.D. (vice chair)

Renato Aguilera, Ph.D.

Anthony DePass, Ph.D.

Wilfred Denetclaw, Ph.D.

William Eckberg, Ph.D.

Pearl Fernandes, Ph.D.

Vincent Hollis, Ph.D.

Raquell Holmes, Ph.D.

Andrea Morris, Ph.D.

Sandra Murray, Ph.D.

Laura Robles, Ph.D.

Peter Satir, Ph.D.

Kevin Davis (ad hoc) postdoctoral fellow
American Cancer Society

Morehouse College

University of Texas, El Paso

Long Island University

San Francisco State University

Howard University

University of South Carolina, Sumter

Howard University

Boston University

Haverford College

University of Pittsburgh, School of Med

California State University, Dominguez Hills

Albert Einstein College of Medicine

University of Pittsburgh, School of Med achievement. Many African Americans are performing well below grade levels on standardized tests that measure mathematics and reading skills. By 1988, according to National Assessment of Education Progress scores, "African Americans and Hispanics had stopped catching up to their white and Asian American contemporaries. Today, the disparity remains troubling, persistent, and large" (Barnes, 2004, p. 68). Public education has suffered over the last 50 years since Brown, and the scourges of animosity and resistance have given way to hopelessness and apathy in many large school districts-places where the majority of underrepresented students reside and the pool from which the most selective institutions of higher education draw their minority populations.

What can the ASCB MAC do to encourage better development of minority scientific talent? Following is a small checklist of minority activities currently sponsored by the ASCB MAC to increase the numbers and better train minorities already in the pipeline:

- The ASCB MAC's Visiting Professors program matches ASCB members with faculty from minority-serving institutions (MSIs) to work for 6 to 8 weeks each summer in an ASCB member's lab. Last year, the ASCB MAC funded six pairings of scientists around the country. The Visiting Professors program promotes scientific integration in many ways: as a collaboration of scientists from different types of institutions, different ethnic backgrounds, and different areas of research.

- The ASCB MAC's Linkage Fellows program provides faculty from MSIs with the opportunity to attend the ASCB Annual Meeting and meet with the MAC chair and MAC liaison to discuss issues related to professional development, research, and publication.

- Under an NIH/National Institute of General Medicine Minority Access to Research Careers grant, the ASCB MAC funds travel awards to students and faculty to attend the ASCB Annual Meeting and present posters. The MAC also provides travel awardees with the opportunity to attend a MAC-hosted Saturday Mentoring Symposium, MAC poster award luncheon, and the annual E.E. Just Lecture. The travel awards and the Linkage Fellows program allow students and faculty the opportunity to network with each other and the larger science community at the ASCB Annual Meeting and other conferences.

- As part of the MARC grant, the ASCB MAC sponsors students to attend summer courses at the Marine Biological Laboratory and the Friday Harbor Laboratory and workshops offered by the Histochemical Society.

\section{REDEFINING THE DREAM: INTEGRATION VERSUS EDUCATION?}

As a minority professor in the Department of Biochemistry at Boston University's School of Medicine, ASCB member Dr. Bruce A. Jackson is confident of the continued need for Brown and Michigan: "five decades after Brown, we find in the scientific professions of our nation an absence of peopleof-color, who comprise nearly 35 percent of our population." Jackson concludes that "although tremendous advances have been made since Brown, we must be as vigilant and as unyielding today as those whose efforts fifty years ago have made our careers and professional opportunities a current reality."

In the last 40 years, the nation's attempts to achieve the principles of school integration have met with uneven academic success. There are many who argue for a modification to the ideal of racial integration in favor of a model that emphasizes desegregation's core goal: minority achievement. Former Yonkers, NY, NAACP official Kenneth W. Jenkins was removed from his post in 1996 by NAACP national leaders for openly supporting the view that "integration is [not] the goal. The goal is quality education" (Irons, 2002, p. 346).

As we move ahead, the ASCB and MAC remain committed to goals that support quality education and the training of minorities in science and to programs that target minority scientists at both MSIs and majority institutions. The MAC activities promote scientific integration, which has produced lasting relationships and fostered a growing awareness of the needs and strengths of different kinds of institutions and faculty. Every ASCB MAC program seeks to instill in its participants a sense of belonging to the national and global scientific community-one of the truest forms of integration.

\section{REFERENCES}

American Council on Education. (2003, October). 20th Anniversary: Minorities in Higher Education Annual Status Report, Washington, DC: American Council on Education, 85-86.

Barnes, J.E. (2004). Now the focus shifts from integration to achievement for all. U.S. News and World Report (March 22-29, 2004), 68. 
Bok, D. (2003). Closing the nagging gap in minority achievement. Chron Higher Educ. (October 24), B20.

Clarke, Julia V. (n.d.). Minorities in Science and Mathematics: A Challenge for Change. Virginia Parent Information and Resource Center. http://vpirc.net/education/articles/math.shtml (accessed May 20, 2004)

Cohen, J.J. (2003). The consequences of premature abandonment of affirmative action in medical school admissions. JAMA 289, 1143.

Irons, P. (2002). Jim Crow's Children: The Broken Promise of the Brown Decision, New York: Viking Press.

Jackson, S.A. (2004, February 14). The perfect storm: A weather forecast. Speech delivered to the American Association for the Advancement of Science Annual Meeting, Seattle, WA.
National Science Foundation.(1996). Women, minorities and persons with disabilities in science and engineering. http://www.nsf.gov/sbe/ srs/nsf96311/htmpdf.htm (accessed April 1, 2004).

National Science Foundation. (1999). Division of Science Resources Statistics, Survey of graduate students and postdoctorates in science and engineering, Appendix Table 4-7: Top 20 schools enrolling Asian, black, Hispanic, and American Indian/Alaskan Native graduate students in science and engineering. http:// www.nsf.gov/sbe/srs/nsf03312/append/c4/at04-07.pdf (accessed April 2, 2004).

Oakes, J. (1990). Multiplying Inequalities: The Effects of Race, Social Class, and Tracking on Opportunities to Learn Mathematics and Science, Santa Monica, CA: RAND Corporation. 